\title{
Native Title vs land rights: is change more effective when it is achieved through social and political activism or the courts?
}

\author{
Mia Dabelstein
}

\begin{abstract}
This paper explores the effectiveness of social and political activism in achieving change compared with pursuing legal action through the courts, analysing campaigns to achieve Aboriginal land rights and the Mabo case.
\end{abstract}

Keywords: activism; change; land rights; native title; Mabo case

Both social and political activism and the courts have experienced varied degrees of effectiveness in achieving change. In discussing the statement accurately, the concept 'effective change' must be defined. The definition varies between the two conceptual mechanisms being discussed. Within the realm of social and political activism, 'effective change' can inhabit a much broader and more fluid definition. In this definition, if any aspect of the goals set out are achieved it is deemed a successful action and therefore 'change' is effective (Eckstein 1988, p. 798). The definition applicable to the courts is much more rigid, however it is also simpler to determine. My primary focus in discussing the different avenues will be the comparison between land rights and Native Title. The land rights movement has a long history of social and political activism, with many wins and losses. The Mabo decision led to the Native Title Act 1993 (Cth), showing how it was integral to the future of Native Title in Australia and is an example of judicial activism. Engaging in Indigenous activism is a thoroughly political act and goes hand in hand with social identity discourse that places the political within the personal (Isenburg 1992, p. 452). Furthermore, through this inherent politicisation of Indigeneity, many of the events and landmarks of the land rights movement appear in the history of both social and political activism and the courts, in that many cases that were unsuccessful judicially but still provided momentum for the movements.

Native Title and land rights differ immensely in the affect they have on Aboriginal ownership and control of lands. Land Rights pertain to legislative responses to social and political movements led by Aboriginal activists (Kelly \& Behrendt 2007, p. 75-76). In contrast, Native Title was born within the courts from Mabo (No 2) (Kelly \& Behrendt 2007, p. 76). Land rights have been on the forefront of Aboriginal activism since colonisation. Land Rights are a package of laws that seek to 
compensate for the large-scale violence and dispossession against Aboriginal people. In contrast, the concept of Native Title began a decade later and focuses on both rights and particular cultural attachments to a place. While we now largely see Aboriginal people as a homogenous group, there is substantial diversity in laws and customs throughout the hundreds of different language groups across the continent, and in that, large variations to the connections and adaptations these groups had to their country (Howden 2001, p. 62). Within the homogeneity there is heterogeneity. However, there do exist cross-cultural characteristics identified within many Indigenous knowledge systems (Howden 2001, pp. 62-63). Simply put, it has been socially established that Aboriginal people have the right to their lands, however, having the right to pursue the regaining of their land is no guarantee of regaining control over it.

While various Land Rights movements have been in existence since the 1860s at least, the modernday movement traces its origins to 1963 when the Yolgnu people from the Yirrkala settlement in the Northern Territory presented the Australian Parliament with the bark petitions. This was the first document dictating traditional laws and customs that was recognised by the Commonwealth Parliament and was successful in gaining traction and recognition. However, the Gove Land Rights Case, as its subsequent court case came to be known, failed in 1971. The Wave Hill Walk Off was another unprecedented and significant action undertaken by Aboriginal people. In 1966, Vincent Lingiari, of the Gurindji tribe, led his people to strike for better conditions and pay on the cattle station they were employed on. The cattle station existed on their traditional lands and as the strike gained momentum it evolved into a demand for the right to regain control of their lands. Prime Minister Gough Whitlam famously 'handed' back the land by giving Vincent Lingiari the deeds to the land, and symbolically placing a handful of Daguragu soil into his hand.

While not linked directly to the land rights movement, Aboriginal social and political activist groups had been constantly active. The Freedom Rides that took place in the 1960s drew national attention to poor standard of Aboriginal education, housing and health. In drawing attention to these issues, it increased public pressure on the Australian government to act on discrimination towards Aboriginal people. Furthermore, it was integral to the latter half of the campaign for the 1967 referendum. The success of the referendum is indicative of political and social activism enacting effective change through campaigning and community organising.

Despite the failure of the Gove Land Rights Case 1971, there was a significant political response with the Whitlam Government commissioning an inquiry into how traditional rights to land may be recognised in the Northern Territory (Keon-Cohen 2000, p. 895). The Whitlam Government also drafted the Northern Territory Land Rights (Northern Territory) Act, however due to the change in government, when it was finally passed by the Fraser Government in 1976 it had been watered down to allow large concessions for mining and graziers (Cook \& Goodall 2013, p. 176). At this point, the movement began to stall and it became clear that land rights and other Aboriginal issues needed a kick-start (Cook \& Goodall 2013, p. 175). As is indicative of the entire fight for equal and civil rights by the Aboriginal community, there lay the issue that constitutionally, the federal government could not legislate issues pertaining to land (Cook \& Goodall 2013, p. 175). Despite this, the Whitlam Government attempted to legislate for land rights within the areas they were constitutionally able to; the Northern Territory, the ACT and Jervis Bay. To an extent, the ousting of the Whitlam Government to the Fraser Government coinciding with the 'Wranslide' election 
(Norman 2015, p. 29) cancelled out the conservative change in federal government as it became increasingly understood that the fight for land rights needed to be fought on a state level. Prior to this, the New South Wales Aborigines Act "was amended to form the 'Aboriginal Lands Trust' in 1973" (Cook \& Goodall 2013, p. 175).

The Land Rights conference in 1977 was the first time that land rights had been spoken about as a cohesive issue. Aboriginal community leaders and the Black Defence Group used an already popular event, the Aboriginal Football Knockout, to bring together Aboriginal people from across the state to talk about Land Rights (Cook \& Goodall 2013, p. 179). The conference demanded the full-scale recognition of Aboriginal Land Rights and to set up the New South Wales Aboriginal Lands Council, and the abolishment of the Aboriginal Lands Trust, which was seen as a largely ineffective and constrained structure due to being an unelected nine-member advisory council, who could only submit claims to 'vacant Crown land' (Norman 2015, p. 42; Cook \& Goodall 2013, p. 180). The Black Defence Group had immense success in halting the Aboriginal Lands Trust selling of land. In setting up the NSW Land Council at the 1977 conference, they began travelling around the state, meeting with Aboriginal communities and developing coherent and communal goals. They concentrated heavily on building communications in rural areas. This was integral to future meetings when the Wran Government was re-elected in 1981 and saw the establishment of the Department of Aboriginal Affairs, headed by new minister Frank Walker. Walker's initiation of discussions mobilised the NSW Land Council to increase their communications even more in order to develop "common political strategies" (Cook \& Goodall 2013, p. 209). The new social movements that gained global popularity in the mid-seventies as well as increased frustration led to an increasingly nationalised approach to garnering attention as Aboriginal groups began to collectivise and appear as a more homogenous group (Cohen 1985, p. 663; Goodall 1995, p. 112). The catalytic increased interest by Aboriginal people in regaining ownership of their land became the unifying issue that was in the forefront of all Aboriginal communities across the country. While the Aboriginal community was communally engaged with and fighting for control of their traditional lands, it was necessary for this to be fought on a state level. In coming together to as an Aboriginal community, leaders brought with them groups they were associated with and alliances were formed with churches, unions and various other organisations. Out of these alliances, new agencies like The Trade Union Committee for Aboriginal Rights (TUCAR) were established. This brought in support from the wider community, not just Aboriginal people. The community was slowly regaining momentum through increased social and political activism as they aligned themselves with the political Left, increased community control and grassroots activism and opposed insufficient government structures (Norman 2015, p. 34). Through community organisation and activism, the Black Defence Group and the NSW Lands Council were able to influence the policy of the Australian Labor Party (ALP) at their conference in 1978. As the unions were integral to the ALP's extra-parliamentary support, TUCAR then permeated into the structures of the ALP, therefore changing the party and its politics from the inside out (Cook \& Goodall 2013, p. 129).

While the Aboriginal Land Rights Act 1983 (NSW) (ALRA) was established to return land in New South Wales to Aboriginal people, it did not formally and legally acknowledge the rights and interests Aboriginal people have in land and water and their laws and customs that long pre-dated European arrival. Unlike Native Title, it did not attempt to reconcile Aboriginal customs and laws 
and was a legislative response to the social and political activism that was gaining strength and pushing the movement into the forefront of Australian activism.

In reviewing Native Title claims, it must be proved that there has been an ongoing and uninterrupted connection to the land within the claimants' traditional laws and customs. Within the multitude of different Aboriginal tribal and language groups exists vast differences in law and custom, which has previously been a hindrance to having a united front. However, there are overlapping concepts that can be applied to determining whether Native Title exists (Howden 2001, pp. 61-62). These include but are not limited to: "a close interdependence between knowledge, land and spirituality; the passing down of knowledge through generations; oral exchange of knowledge ... according to customary rules and principles; and the existence of rules regarding secrecy and sacredness which govern the management of knowledge" (Davis 1999, p. 4). This cultural significance to land held by Aboriginal people is a unique concept, alien to western concepts of land and ownership (Howden 2001, p. 68). Indigenous connection to land relates "to culture and artistic expression and to physical survival and environmental management" (Howden 2001, p. 60).

The doctrine of Native Title has its origins in the case of Mabo v Queensland (No. 2) when the High Court made its decision to overrule the claim that Australia was 'terra nullius'. There are substantial similarities within the Gove Land Rights Case 1971 and Mabo. Mabo (No. 2)'s success created the Native Title Act 1993 (Cth) and the National Native Title Tribunal (NNTT) which were "enacted in order to provide an administrative structure to channel native title claims" (Kelly \& Behrendt 2007, pp. 76-77). In 1982, Eddie Mabo lead a group of people from the island of Mer in the Torres Strait to claim ownership of the Murray Islands. In a pre-emptive movement, the Queensland government passed legislation to extinguish without compensation any rights Torres Strait Islanders had to land prior to sovereignty in 1979 (AIATSIS 2008). This legislation was challenged in the High Court, which decided that it was in violation of the Racial Discrimination Act 1975 (Cth). This became known as Mabo (No. 1) as they could now proceed with their original case. In handing down the judgement for Mabo (No. 2), the judges decreed that "the Meriam people are entitled as against the whole world to possession, occupation, use and enjoyment of the lands of the Murray Islands" (Mabo v Queensland 1992). This eliminated the legal fiction of the doctrine of terra nullius, paving the way for Aboriginal groups to claim Native Title in the future and therefore showed that the courts could be a successful avenue for change.

Despite the success of Mabo (No. 2) the case of the Wik Peoples v Queensland (1996) show the limitations of the Native Title Act 1993 (Cth). The two claims made by the Wik people and the Thayorre attempted to claim that despite pastoral and mining leases, their connection to the land had not been interrupted or extinguished. In a similar but contrasting vain, the Yorta Yorta people made a claim on a parcel of 'vacant Crown Land'. However, their rejected claims were rejected on the grounds that the connection had been interrupted and they had not sustained their traditional laws and customs on the land in question. The inability to recognise this connection presents the ideological incompatibility of traditional Aboriginal law and customs and Australia's Western legal system and furthermore, "Native Title does not have the scope to recognise and protect traditional knowledge" (Howden 2001, p. 61). The rejection of claims made by the Wik and Thayorre people show how the Native Title Act 1993 (Cth) upholds the colonial past. The failure of the Yorta Yorta claim shows how traditional Aboriginal laws are irreconcilable within our Western legal system. 
While Mabo (No. 2) gave hope by overturning terra nullius, the Native Title Act 1993 (Cth) needs to be reformed.

Aboriginal history is inherently a history of political and social activism. Only in recent years have the courts existed as a viable avenue for change. Therefore, in the context of Aboriginal history and the doctrine of Native Title and the land rights movement, while both have had successions of wins and losses, it has been primarily through the grassroots campaigning, community organising and thus social and political activism that Aboriginal people have been able to progress forward.

\section{References}

Aboriginal Land Rights Northern Territory Act 1976 (Cth).

Australian Institute of Aboriginal and Torres Strait Islander Studies, 2011, Case Summary: Wik Peoples v Queensland, viewed 17 June 2017, http://aiatsis.gov.au/publications/products/casesummary-wik-peoples-v-queensland.

Australian Institute of Aboriginal and Torres Strait Islander Studies, 2008, Mabo Case, viewed 17 June 2017, http://aiatsis.gov.au/explore/articles/mabo-case.

Cohen J. L. 1985, Strategy or Identity: New Theoretical Paradigms and Contemporary Social Movements, Social Movements, vol. 52, no. 4, pp. 663-716, www.jstor.org/stable/40970395.

Cook, K. and Goodall, H. 2013, Part 3: Land Rights NSW 1980s, in Making Change Happen: Black and white activists talk to Kevin Cook about Aboriginal, Union and Liberation Politics, Published by ANU E Press, The Australian National University, Canberra, pp 175-204 / 235, http://pressfiles.anu.edu.au/downloads/press/p245561/pdf/whole6.pdf.

Davis M. 1999, Indigenous Rights in Traditional Knowledge and Biological Diversity: Approaches to Protection, Australian Indigenous Law Reporter, vol 4, pp. 1-32.

Eckstein, H. 1988, A Culturalist Theory of Political Change, American Political Science Review, vol. 82, no. 3, pp. 789-804, https://doi.org/10.2307/1962491.

Goodall, H. 1995, 'New South Wales' in A. McGrath (ed) Contested Ground: Australian Aborigines under the British Crown, St Leonards, NSW: Allen \& Unwin, pp 55-120.

Howden K. 2001, Indigenous Traditional Knowledge and Native Title, University of New South Wales Law Journal, vol. 24, no. 1, pp. 60-84, http://www.unswlawjournal.unsw.edu.au/sites/default/files/12_howden.pdf.

Isenburg, N. 1992, The Personal is Political: Gender, Feminism and the Politics of Discourse Theory, American Quarterly, vol. 44, no. 3, pp. 449-458, https://www.jstor.org/stable/2712985.

Kelly, L. and Behrendt L. Y. 2007, Creating Conflict: Case Studies in the Tension Between Native Title Claims and Land Rights Claims, Journal of Indigenous Policy, vol. 8, pp. 73-102, http://hdl.handle.net/10453/6006. 
Keon-Cohen B.A. 2000, The Mabo Litigation: Personal and Procedural Account, Melbourne University Law Review, vol. 24, no. 3, pp. 893-951, http://search.informit.com.au.ezproxy.lib.uts.edu.au/fullText; $\mathrm{dn}=20012013 ;$ res=AGISPT $>$.

Mabo and Others $v$ Queensland 1992 (No. 2) 175 CLR 1 (1992) HCA 23.

Mabo v Queensland (No. 1) (1988) 166 CLR 186.

Milirrpum v Nabalco Pty Ltd (1971) 17 FLR 141.

National Native Title Tribunal, 1999, Native Title an overview, pamphlet, National Native Title Tribunal, viewed 17 June 2017, http://www.nntt.gov.au/Information\%20Publications/Native\%20Title\%20an\%20overview.pdf.

Native Title Act 1993 (Cth).

Norman, H. 2015, Government, Aborigines and Power: the NSW Land Rights Inquiry, Chapter 2 in 'What Do We Want? a political History of Land Rights, Aboriginal Studies Press, Canberra, pp 2949, https://ebookcentral.proquest.com/lib/UTS/detail.action?docID=2035888.

Racial Discrimination Act 1975 (Cth).

The Wik Peoples $v$ State of Queensland \& Ors; The Thayorre Peopole v State of Queensland \& Ors (1996) 187 CLR 1.

(C) 2018 by the author. This article is distributed under the terms and conditions of the Creative Commons Attribution license (http://creativecommons.org/licenses/by-nd/4.0/). 